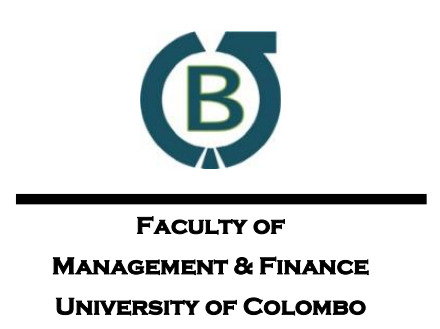

Colombo

Business

Journal

INTERNATIONAL JOURNAL OF

THEORY \& PRACTICE

Vol. 11, No. 02, December, 2020

\title{
The Impact of Lagged R\&D Expenses on Firm Performance: Empirical Evidence from the BSE Healthcare Index
}

\author{
Abhijit Sinha $^{\mathrm{a}} \bowtie$, Keyarani Mondal ${ }^{\mathrm{a}}$ \\ ${ }^{a}$ Department of Commerce, Vidyasagar University, India
}

\begin{abstract}
The study finds the impact of lagged Research and Development expenditure on financial performance. The investigation analyses 69 pharmaceutical companies included in the BSE healthcare index (India) using secondary data for the period of 2008 to 2017. The two dependent variables which are considered separately are Return on Asset (ROA) and Return on Equity (ROE). The two estimated regression models show that both the lagged value and its quadratic term have a significant influence on the accounting-based measures. With regard to the control variables, size and leverage are found to influence negatively whereas liquidity poses a positive effect on these two accounting-based performance measures. The article contributes by highlighting that the true relationship between $R \& D$ and financial performance is represented by a U-shaped curve as evident in few other studies.
\end{abstract}

Keywords: Lagged R\&D, Firm Performance, ROA, ROE, BSE Healthcare Index

\section{Received:}

17 March 2020
Accepted revised version:

26 October 2020
Published:

31 December 2020

Suggested citation: Sinha, A., \& Mondal, K. (2020). The impact of lagged R\&D expenses on firm performance: Empirical evidence from the BSE healthcare index. Colombo Business Journal. 11(2), 114-141.

DOI: http://doi.org/10.4038/cbj.v11i2.66

(C) 2020 The Authors. This work is licensed under a Creative Commons Attribution 4.0 International License which permits unrestricted use, distribution, and reproduction in any medium, provided the original work is properly cited.

\abhijitsinha_091279@rediffmail.com: (iD) https://orcid.org/0000-0003-3034-0930 


\section{Introduction}

Profitability of firms is a necessity and is the social responsibility of a business (Friedman, 1970). Research and Development (R\&D) is critical for any firm as it leads to growth by elevating productivity levels and developing innovative processes (Guo et al., 2016). It is considered to be an important input that adds value to the performance of businesses (Chen et al., 2019). Spending under this head is considered important as it helps in the diversification of activities making firms more competitive (Baptista \& Karaoz, 2011; Deloof, 2003) and improving the capacity to export (BeiseZee \& Rammer, 2006). It is considered as a source that produces knowledgeable employees in an environment of a learning organisation. The relevance of $R \& D$ is evident in the present age of knowledge economy which is led by the power of new ideas, thinking and innovation. Taking cues from the resource-based theory given by Barney, one shall understand that sustainable competitive advantage can emerge in an enterprise only if it is in possession of resources which are valuable, rare, inimitable and organised. Since firms need to create tacit resources which is a difficult task, businesses should consider R\&D as a regular exercise which will help to position themselves ahead of others that is reflected in profitability through the sale of new products, services and implementation of efficient production processes, thereby enabling firms to open new markets or minimise production costs (Naik et al., 2012).

In the present world of intense competition, businesses have understood the risk of imitation and recognised the crucial role of innovation due to which they allocate sufficient resources towards R\&D (Guo et al., 2016), thereby generating competitive strength (Shelton \& Percival, 2013) which impacts profitability levels. On a similar note, Dai and $\mathrm{Yu}$ (2013) mention that corporates incur this expenditure to bring about improvements in their innovative and absorptive capacities that get transmitted into performance (Gu, 2016; Mulero Mendigorri et al., 2016) which is commonly measured using Return on Asset (ROA) and Return on Equity (ROE). The former is important in cases where the research is viewed from the perspective of managers and all stakeholders whereas the latter is relevant in investor-centric studies. ROA is considered in the studies of Simerly and $\mathrm{Li}$ (2000) and Sheikh et al. (2013) to name a few, whereas Chaklader and Chowla (2016) look at ROE. The study by Le and Phan (2017) takes into account both ROA and ROE. In this study, for measuring profitability, both these measures are considered. The connection between investment on R\&D and effect on profitability is well explained by McDaniel (2002) where the author argues that the direction and extent of effect depends on the result of set-off between benefits (returns) arising from the new products/services and the cost of investment. 
It is apparent that $\mathrm{R} \& \mathrm{D}$ expenditure has a positive impact on performance (Ayaydin \& Karaaslan, 2014; Chai, 2012; Liao, 2013). However, there are contributions that highlight the negative aspects arising from risk connected with this expenditure (Shi, 2003). Thus, there are also research studies that are not so optimistic about the consequence of R\&D investments because of the uncertainty in the outcome of the spending as pointed by Griffith et al. (2006) with regard to the improvements in productivity. Peters et al. (2013) argue that this benefit differs on the basis of experience in the area of R\&D. Brenner and Rushton (1989) further mention that the sales growth is comparatively higher for those firms that spend more than the average. Due to the lack of congruence in researchers' opinions, the study aims to re-look at how R\&D activities impact performance which can, therefore, guide corporate managers to take policy decisions in this regard.

Apart from the direction of impact, the other question that confuses researchers is whether the investment in $R \& D$ generates benefits in the same year or with a time lag. If one looks into the system of knowledge transfer, it will be observed that it passes through different phases which include acquisition, communication, application, acceptance and assimilation which, therefore, makes it logical to consider the issue of time lag between the incurrence of expenditure and realisation of benefits in the form of revenue generation (Falk, 2012; Ravenscraft \& Scherer, 1982; Tubbs, 2007). Some of the previous studies that have already considered the effect of lagged expenditure include those of Chai (2012), Liao (2013) and Lu and Wang (2011). The other pertinent question that is not yet so deeply explored is the nature of the relationship (linear or non-linear) between R\&D and performance.

From the theory in Economics, we know that shape of a curve depends on the marginal utility of the R\&D expenditure (Fredriksson \& Wikberg, 2015). Few authors have however used the term marginal product of R\&D expenditure (Peters et al., 2013; Ren \& Wang, 2013). The shape of the curve depends on the nature of marginal utility. If marginal utility remains constant, it implies the existence of a linear form, otherwise non-linearity would be the characteristic of the curve. The present investigation adds knowledge to the literature which is already available by not just checking the relationship between the two, but also identifying the level of expenditure beyond which the performance level reverses direction. This academic contribution will add a new dimension to this field of study which can be of use to corporate leaders by giving more concrete answers to the questions of direction, significance and optimal level of R\&D expenditure. The details of previous studies are given in the next section on literature review. 
The study is very relevant in the Indian context because the country ranks low at 41 out of 100 countries (World Bank Group, 2020). The spending on R\&D which is even less than $1 \%$ of its Gross Domestic Product on R\&D places it far below countries like Israel, South Korea, Japan, Germany, US, France and other developed economies of the globe. Thus, in spite of knowing the importance of R\&D, at the country level, there is a lack of action. In this study, the researchers examine the connectedness between $R \& D$ expenditure by Indian corporates and financial performance from a new perspective.

The contribution of the paper lies in three aspects: (a) The effect of lagged $R \& D$ expenditure on performance is explored. (b) The nature of relationship between R\&D expenditure and performance with regard to its linearity or non-linearity is examined; therefore, whether the expenditure gives increasing and/or decreasing returns can be conceptualised and (c) The level of R\&D expenditure at the point of inflexion is identified, which will guide managers to decide how much to spend under this head. The research is timely and appropriate because it determines the effect of R\&D on performance and very few studies have assessed the non-linearity of the relationship.

On the basis of the lacuna in previous research, the following objectives are set: (a) To find the effect of R\&D on firm performance (both ROA and ROE), (b) To examine the linearity of the relationship between the two, and (c) To identify the point of inflexion in case there is a non-linear relationship between them.

The rest of the paper is arranged as follows. The next section lays the theoretical framework and mentions the hypotheses for the study. This is followed by an explanation of the research design and the framework for considering variables for the study. Then findings of the study are presented, and the paper concludes with some implications for practice based on findings.

\section{Theoretical Framework and Hypotheses}

The issue of R\&D and its connection with performance has been an area of interest for researchers. The study of previous research contributions shows a wide coverage of studies. In the Indian context, several industries have been covered which include pharmaceutical (Kumar \& Saqib, 1996; Mishra, 2011); manufacturing (Pradeep et al., 2017; Jaisinghani, 2016; Joseph, 2011; Naik et al., 2012; Parameswaran, 2010; Pradhan, 2011; Sharma, 2011), and small and medium enterprises (Rehman, 2016). In the context of Asia, there are studies in Pakistan (Ghaffar \& Khan, 2014), Jordan (Freihat \& Kanakriyah, 2017), China (Wang, 2011; 
Zhu \& Huang, 2012), Japan (Rao et al., 2013), Taiwan (Hsu et al., 2013) and Iran Khajavi \& Sadeghnia, 2016). There are also several research papers in the context of Europe which include the studies of Al-Horani et al. (2003), Griffith et al. (2006), Parcharidis and Varsakelis (2007) and Garcia Osma and Young (2009) to name a few.

It is evident that the area has been explored by researchers but there is a lack of congruent relationship between spending on R\&D and financial performance (Beld, 2014; Fredriksson \& Wikberg, 2015; Rao et al., 2013; Zhu \& Huang, 2012). The studies of Ayaydin and Karaaslan (2014) and Kumar and Saqib (1996) find a positive effect of R\&D intensity on financial performance which contradicts the findings of Khajavi and Sadeghnia (2016), Parcharidis and Varsakelis (2007), Beld (2014) and Ayaydin and Karaaslan (2014). If one looks into the mechanism by which knowledge is transferred through the R\&D process, one may be logical in stating that it takes time to realise results after the costs are incurred. The step-wise movement from knowledge acquisition to assimilation through application and acceptance gives scope to researchers to test whether lagged expenditure has any influence on present performance (Bae et al., 2017). In a few studies the issue of lag is considered (Chen et al., 2019; Falk, 2012; Jirasek, 2017; Pantagakis et al., 2012; Parcharidis \& Varsakelis, 2007; Tubbs, 2007). However, the lack of concrete evidence from previous researches provides further scope to explore the issue from a different context which may help in unravelling the hidden truth. The contradiction in findings is seen from the studies of X.C. Zhao and Wu (2013) and Lu and Wang (2011) which find a negative impact of present expenditure on performance, but a positive and significant effect of one-year lagged expenditure. On the other hand, positive effect is established in the contributions of Liao (2013) and Zhu and Huang (2012). AlHorani et al. (2003) points to the effect of $R \& D$ expenses on stock returns in the United Kingdom. In a Taiwan-based study, Hsu et al. (2013) establishes a negative relationship between $R \& D$ expenditure and profitability of companies which matches the conclusions of Khajavi and Sadeghnia (2016), Beld (2014), Ayaydin and Karaaslan (2014) and Parcharidis and Varsakelis (2007). Thus, studies have arrived at varying inferences which thereby keeps the option open to investigate further. It is pertinent to mention here that with regard to the studies that determine the effect of $\mathrm{R} \& \mathrm{D}$ expenditure and performance, only a handful of research consider non-linear relationship (Beld, 2014; Wang, 2011; Fredrikson \& Wikberg, 2015; Pantagakis et al., 2012; Parcharidis \& Varsakelis, 2007). In other words, majority of the previous contributions drew their conclusions on the basis of linearity assumption of the model, which is a major flaw in the existing contributions. 
If we now look at the status of studies made in the Indian context, we see that there are a handful of research studies connecting R\&D and business performance and few others have looked some other areas. Pradhan (2011) identifies the factors that determine R\&D spending which is similar to the contribution of Parameswaran (2010) that looks at the effect of international trade on R\&D spending by Indian manufacturing firms. Mishra and Chandra (2010) study the effect of merger and acquisitions on performance in the case of pharmaceutical industry in the new patent regime. Sharma (2011) in another research makes a comparison between firms who invest lump sum amounts on R\&D vis-à-vis those who do not and finds that expenditure intensity has an impact on productivity. Joseph (2011) in the discussion on Indian pharmaceutical industry finds the effect of $R \& D$ expenditure on risk. Naik et al. (2012) in the study on manufacturing firms establishes a positive effect of R\&D on firm value measured using Tobin's Q. In another such study, Jaisinghani (2016) shows a profit persistence arising from $R \& D$ intensity in the case of listed Indian pharmaceutical firms. An interesting study by Pradeep et al. (2017) finds a spill over effect of investment in $R \& D$ on the productivity levels of foreign and Indian manufacturing firms. Rehman (2016) in a cross-country study identifies the positive influence of internal and external $R \& D$ expenditures on both product and process innovation. The study by Purkayastha et al. (2018) draws a connection between the levels of R\&D expenditure and internationalisation.

The authors are of the opinion that there are no studies in the context of pharmaceutical companies/any other industry in India which look into the effect of lagged $R \& D$ variable on performance. Hence, the present study is pertinent in respect of India since the pharmaceutical industry makes huge investment in R\&D with the expectation of improving market share and financial performance. But researchers comment that there is a waiting time before benefits flow to the firm. With respect to Indian studies, the study by Dharni (2017) focuses on the link between R\&D and performance but applies a linear model without testing whether model specification holds true. It thereby ignores the quadratic relationship which this study finds to be relevant and seen in some of the literature based on other parts of the world. Hence, this study looks at the connection from a new angle.

Some of the Indian studies that look into the relationship between $R \& D$ and aspects other than the firm performance include that of Joseph (2011) which studies the scenario of $R \& D$ in the Indian pharmaceutical sector. The study by Mahajan (2011) focuses on the new $R \& D$ paradigms that have arisen after the introduction of The Agreement on Trade-Related Aspects of Intellectual Property Rights (TRIPS). 
The investigation by Tyagi and Nauriyal (2016) looks at the determinants of Research and Development Intensity (RDI) in the Indian pharmaceutical industry. The other areas that have been studied with respect to $R \& D$ in the Indian context include impact of Foreign Direct Investments (FDI) on R\&D (Kathuria, 2008), R\&D spillovers and its effect on productivity (Singh, 2016) and determinants of R\&D in manufacturing industry (Thomas \& Narayanan, 2007) and in small and medium enterprises (Pradhan, 2011). Thus, there is a gap due to lack of studies in the Indian industry environment.

Apart from this, the review of literature shows a lack of consensus regarding the relationship between R\&D and firm performance. Additionally, in majority of the literature, there is a lack of focus on lagged R\&D expenditure and its effect on firm performance both in the Indian context and elsewhere. The consideration of the effect of lagged value of R\&D on performance is very logical because of the time factor between incurrence of the expenditure and its effect on performance which is also highlighted by Ho et al. (2005). A similar view is also shared in the works of Falk (2012), Wang and Wu (2012) and Fryxel (1990) where they support the view that the effect of investment on intangible assets will give fruits only after a time lag. It is duly supported by Hall et al. (2009) who cite that since there is a time gap between expenditure and innovation and then to commercialisation, positive effect can be realised only after some time. With regard to the lag period, there is evidence to support that the lag period for R\&D is two and even beyond (Lee \& Choi, 2015). Thus, the importance of lagged variable is evident from the writing in Fredrikkson and Wikberg $(2015$, p.6) which mentions: "The inherent time lag between an R\&D investment and the returns of that R\&D investment is another factor making marginal utility of R\&D dynamic (Yang, 2010)".

The previous foreign researchers make a minimal effort in testing the appropriateness of the equation form before arriving at conclusions on the effect of current or lagged variables. Thus, the earlier findings may prove to be farce as it may have suffered from the problem of functional misspecification. Thus, looking into these aspects, the present study plugs these gaps and tests for the nature of the relationship before arriving at the necessary conclusions which are followed by the identification of the cut-off point of R\&D expenditure (at the point of inflexion).

The findings of this study are extremely relevant for Indian businesses in this era of cut-throat competition and more so as a major chunk of the revenues come from foreign markets. Thus, it is vital to know how R\&D behaves with regard to its impact 
on performance. In other words, if the quadratic form of equation is tested, there is a need to identify the point after which the curve takes an opposite directional movement. This will help managers to understand the level of spending under this head to get benefits. The $R \& D$ is measured using the expenditure to sales ratio on a one-year lag basis. Thus, the potential gains arise after a certain level of lagged RDI. This concept is similar to the issue of diversification based on number of securities. As per the discussions in portfolio management, it should be kept within 30, as addition of further securities does not reduce the portfolio risk.

On the basis of the above discussion, the two alternative hypotheses which are posited are:

$\mathrm{H}_{1}$ : There is a significant effect of lagged $\mathrm{R} \& \mathrm{D}$ expenditure on firm performance.

$\mathrm{H}_{2}$ : There is non-linearity in the effect of lagged $\mathrm{R} \& \mathrm{D}$ expenditure on firm performance.

\section{Research Design and Definition of Variables}

The different elements of the research design and definitions of relevant variables are as follows:

\section{Sampling and Data}

The investigation initially started with coverage on all the 69 pharmaceutical companies that are included in the Healthcare index in the Bombay Stock Exchange (India). The reason behind the selection of this index in particular is that the pharmaceutical sector is among the sectors that spend substantially on R\&D which is the focus of the study. Thus, purposive sampling is used for the selection of sample. However, while handling data, it was observed that there is incompleteness in data for 31 companies which were therefore not considered for the purpose of the research. The study is based on secondary data of 38 companies for the period, 2008 to 2017 which is collected from the Capitaline database. The panel is, therefore, a balanced one.

\section{Research Methods}

The researchers consider 38 pharmaceutical companies over a period of 10 years. Hence, the data arrangement is in the form of a panel and, therefore, panel regression method is applied for this research. But prior to its application, some pre-estimation tests are performed, which include testing for multicollinearity and unit root apart from the application of summary statistics and correlation matrix. Then the diagnostic test to check for heteroscedasticity is performed. 
There are two regression models that are estimated in the present study.

Model 1: The dependent variable is ROA and the independent variables are RDILAG, RDILAGSQ, FIN_RISK and LIQUIDITY. The panel regression equation is:

$$
\begin{aligned}
R O A_{i t}= & \alpha_{0}+\beta_{1} R D I_{-} L A G_{i t-1}+\beta_{2} R D I_{-} L_{L} A G S Q_{i t-1}+\beta_{3} \text { FIN }_{-} R I S K_{i t}+ \\
& \beta_{4} \text { LIQUIDITY }_{i t}
\end{aligned}
$$

where, ' $t$ ' is used for the time series element, ' $i$ ' for the cross-sectional unit, ' $\alpha_{0}$ ' is a constant term representing the intercept.

Model 2: The dependent variable is ROE and the independent variables are RDILAG, RDILAGSQ, FIN_RISK and LIQUIDITY. The panel regression equation is:

$$
\begin{aligned}
R O E_{i t}= & \tau_{0}+\beta_{1} R D I_{-} L A G_{i t-1}+\beta_{2} R D I_{-} L A G S Q_{i t-1}+\beta_{3} F_{I N} R I S K_{i t}+ \\
& \beta_{4} L_{\text {LIQUIDITY }}
\end{aligned}
$$

where, ' $t$ ' is used for the time series element, ' $i$ ' for the cross-sectional unit, ' $\tau$ ' is a constant term represent as intercept, and ' $\tau_{0}$ ' is the coefficient.

\section{Consideration of Variables}

Lag of Research and Development Intensity ( $\left.L A G \_R D I\right)$

$\mathrm{RDI}$ is used as a measure to show the quantum of expenditure made towards Research and Development which is thereby used as a proxy for R\&D. The amount is normalised by net sales to maintain parity with firms of different sizes. This variable is used in the studies by Ayaydin and Karaaslan (2014), Beld (2014), Wang (2011), Jirasek (2017), Jaisinghani (2016), Mishra (2011), Naik et al. (2012), Pantagakis et al. (2012), Pradhan (2011), Purkayastha et al. (2018), Vithessonthi and Racela (2016) and Zhu and Huang (2012) among others. However, for the purpose of this research, the effect of $R \& D_{t-1}$ (i.e. with one-year lag) is considered as used in $\mathrm{Xu}$ and Jin (2016) and Garcia Osma and Young (2009) and it is denoted by RDI_LAG. The consideration of the lag variable is logical if one takes cue from the work of Sougiannis (1994) which mentions that almost seven years are required to generate a return up to 200\%. The work of Lee and Choi (2015) which also considers several 
lags to see the influence of $R \& D$ on enterprise value along with the present value found that the current value did not have any influence on performance. The expected sign of this value is negative.

The authors of the present study have decided to exclude the contemporaneous $R \& D$ term from the proposed model for three reasons: Firstly, there are several researchers who strongly mention that investment in assets which are intangible (example research and development) generate benefits only with a time lag (Falk, 2012; Wang \& Wu, 2012; Fryxel, 1990). In a similar tone, Rao et al. (2013) mentions that the investment in R\&D of the current period cannot in any way affect the current performance; there is a lag period between investment and effect on performance. Secondly, there is a high positive correlation of 0.788 between the current and lagged values of R\&D. Thus, the inclusion of both the contemporaneous and lagged terms generates a problem of multicollinearity. Thirdly, there are several studies that evidence insignificant effect of the current value of $R \& D$ but a significant impact of the lagged variable (Rao et al., 2013, Y. H. Zhao \& Xu, 2013, Lu \& Wang, 2011; Chai, 2012).

\section{Square of the Lag Value of RDI (LAG_RDISQ)}

This variable is introduced to check whether the relationship between lagged $\mathrm{R} \& \mathrm{D}$ and firm performance is linear or non-linear. If it is the latter, then experts can determine the optimum point i.e. point of inflexion beyond which the effect on performance takes a turnaround. This variable has been considered in studies such as Fredriksson and Wikberg (2015). The expected sign is positive. As the squared term is used in the model, it depicts a quadratic form of the equation. It is expected that the curve would be U-shaped as seen in the study of Nunes et al. (2012). At the beginning, there will be an immediate negative effect on performance due to incurrence of the huge $R \& D$ cost which will be recovered after amortisation during the first few years. It is to be noted that only incurring expenditure of any amount will not yield benefits. The expenditure on R\&D has to exceed a certain threshold level to yield benefits. Drawing corollary from the concept of economies of scale, in the case of a pharmaceutical industry, the benefits accrue to the firm beyond a certain level of RDI during which net positive impact is observed on performance.

On the basis of the plethora of earlier studies, liquidity and leverage are considered as control variables. 


\section{Liquidity and Profitability}

Liquidity plays an important role not only in the operations of an enterprise but also on profitability (Lamberg \& Vålming, 2009; Pradhan \& Shrestha, 2017). From the basic understanding of finance, one may think that the effect of liquidity on profitability is always negative as observed by Raykov (2017) in recent times. However, there is evidence that do not support this. The studies of Pimentel et al. (2005) and Hirigoyen (1985) argue that due to low liquidity, firms resort to loans which impact profitability and this works like a vicious cycle. Ibrahim (2017) and Pimentel et al. (2005) find a positive relationship between liquidity and financial performance that differs from the finding of Lamberg and Vålming (2009) which finds no relationship. For this research, this aspect is measured using current ratio as used by Makris (2016) and Ayaydin and Karaaslan (2014). The expected sign is negative.

\section{Leverage and Profitability}

Leverage (denoted by FIN_RISK) is employed as it has a direct impact on returns and is included to control for financial leverage. It is computed as the ratio of total debt to total assets as used by Beld (2014) and proxies for the financial leverage. This is another important decision-making area for managers as it impacts profitability due to inclusion of interest-bearing capital (outside funds). The risk arising from employment of debt funds (loans, debentures etc.) has an impact on profitability. Its expected sign is difficult to predict as it depends on the net effect of the 'use' of debt capital. If the returns (benefits) surpass the interest component, then the firm would enjoy a net positive impact, else it will be negative. There have been inconclusive results on the impact of financing decision on profitability. A positive impact is found in the studies of Avci (2016) and Yazdanfar and Ohman (2015) which contradicts the findings in Le and Phan (2017), Khan (2012), Gill et al. (2009) and Yoon and Jang (2005). Since the percentage of debt in total assets in the sector is quite high, the expected sign is negative.

\section{Analysis and Findings}

The data for this investigation is in the form of a panel because it is a combination of several cross-sectional units for several years. Hence, the inferences are drawn with the help of panel regression. The basic computations that are made before its application include summary statistics, correlation matrix and testing for multicollinearity using the Variance Inflation Factor (VIF) whose results are given below. 


\section{Summary Statistics}

Table 1 presents summary statistics of all the variables taken for analysis which help in further exploration (Sasidharan et al., 2015).

Table 1: Descriptive Statistics of Variables

\begin{tabular}{lrrrrr}
\hline Variable & Min. & Max. & Mean & Skewness & Kurtosis \\
\hline ROA & -2158.44 & 219.48 & 12.4046 & -17.999 & 334.868 \\
ROE & -13.03 & 495.12 & 12.2849 & 13.715 & 227.775 \\
RDI_LAG & 0.00 & 355.94 & 9.0596 & 7.652 & 70.635 \\
RDI_LAGSQ & 0.00 & 126689.82 & 921.1699 & 13.668 & 215.884 \\
FIN_RISK & 0.00 & 2135.00 & 31.4915 & 17.860 & 331.034 \\
LIQUIDITY & 0.16 & 8.88 & 2.6888 & 1.369 & 4.176 \\
\hline
\end{tabular}

The descriptive statistics show that the range for all the variables is very high which denotes heterogeneity in the sample companies. The figures point to a wide difference in the pharmaceutical companies which is reflective of the dominating role that a few companies play in the Indian market. Only a handful of players hold a majority of the market share. Due to this, there is a wide range in respect of all the variables. From the values of the skewness, it can be said that the mean surpasses both median and mode in the case of ROE. For ROA, however, the mean is less than the median.

With respect to the positive kurtosis result relating to ROE, it can be said that there exist fat tails which means that there is a chance of earning big positive / negative returns. In the case of ROE, it can be seen that though majority of the companies are clustered towards the mean, there are a few ones which position to the right thereby making it highly positively skewed. However, the opposite is the scenario for ROA which faces a highly negatively skewed data because of the presence of few cases whose mean is far lower than the mean due to which the tail of the distribution gets extended to the left.

In the case of RDI_LAG, the statistics show that there are corporates who did not spend any amount towards Research and Development. On an average, the corporate houses spend $9 \%$ of their sales on R\&D. With regard to financial leverage, the minimum value shows that there are pharmaceutical companies which are debt-free. The liquidity position is such that on average the quantum of current asset is 2.68 times the current liability. 


\section{Correlation Matrix}

Table 2 presents the results of Pearson Product Moment coefficient among the response and explanatory variables.

\section{Table 2: Correlation Matrix}

\begin{tabular}{lrrrrrr}
\hline Variable & ROA & ROE & RDI_LAG & RDI_LAGSQ & FIN_RISK & LIQUIDITY \\
\hline ROA & 1 & $0.115^{*}$ & $-0.270^{* *}$ & $-0.143^{* *}$ & $-0.977^{* *}$ & $0.164^{* *}$ \\
ROE & $0.115^{*}$ & 1 & -0.074 & -0.055 & -0.058 & $0.261^{* *}$ \\
RDI_LAG & $-0.270^{* *}$ & -0.074 & 1 & $0.913^{* *}$ & $0.200^{* *}$ & $-0.192^{* *}$ \\
RDI_LAGSQ & $-0.143^{* *}$ & -0.055 & $0.913^{* *}$ & 1 & 0.097 & $-0.123^{*}$ \\
FIN_RISK & $-0.977^{* *}$ & -0.058 & $0.200^{* *}$ & 0.097 & 1 & $-0.139^{* *}$ \\
LIQUIDITY & $0.164^{* *}$ & $0.261^{* *}$ & $-0.192^{* *}$ & $-0.123^{*}$ & $-0.139^{* *}$ & 1 \\
\hline
\end{tabular}

Note: $* *$ and $*$ denote significance levels $p<0.05$ and $p<0.1$, respectively.

Table 2 shows that both the lagged value of RDI and its quadratic term have significantly negative relationship with ROA though the values are on the lower side. In the case of ROE, though the sign is negative, the influence is insignificant. The relationship between ROA and liquidity is positive but is negatively related to financial leverage. With regard to the correlation between ROE and other variables, the relationship with lagged RDI and its quadratic term is negative, though insignificant. Liquidity is both significantly and positively related with this dependent variable. Financial risk has a negative relationship with ROE, though insignificant.

The test for multicollinearity shows that the VIF value for all the variables is less than 10 , indicating that there is no multicollinearity. However, the inclusion of present RDI creates a multicollinearity problem. Hence, based on previous findings and the logical explanation in different research papers, the current RDI data is not taken into account for the purpose of analysis. Similarly, the data is tested for the presence of heteroscedasticity using the Breusch-Pagan / Cook-Weisberg test. In both the models (see later), it is seen that the $\chi^{2}$ (1) values are 9.86 and 73.32 with p-values of 0.001 and 0.000 respectively. Thus, the null hypothesis gets rejected and we find the data to be heteroscedastic. Thus, to control for this problem, when the final model is estimated, we use the 'robust' option which gives standard errors using the HuberWhite sandwich estimators. 
The Fisher type unit root test is performed based on the Phillips-Perron test. The following hypothesis is tested:

$\mathrm{H}_{0}$ : All panels contain unit root.

$\mathrm{H}_{1}$ : At least one panel is stationary.

It is seen that on the basis of the Fisher type test, all but size variable is found to be stationary. In order to handle the issue, the researchers log-transformed the figures for total assets, sales and number of employees, each of which is representative of size, but the problem continued. Though the variable 'Size' has been excluded from the regression due to the non-stationary characteristic of it, normalizing $R \& D$ terms by dividing them by net sales can be expected to control for the 'size of the firm' indirectly.

\section{Model Selection for Panel Regression}

The data for this study is in the form of a panel with 38 cross-sectional units being studied for over a period of 10 years. Hence, panel regression is applied. In deciding which model to apply of the three (fixed effect, random effect or pooled OLS), the researchers consider application of the Fixed Effect (FE) model as they aim to identify the effect of variables that vary over time. Moreover, there are unit-specific variables that can have an influence of the outcome variable. The other reason behind considering the fixed effect model is that it can remove the effect of time-invariant feature of the units under consideration. As each unit is different and has unique characteristics, there should be no correlation between the error term of the entity and the constant variable which captures the individual characteristics. Though the FE model is considered to be a better fit, it is again verified with the help of a normal statistical procedure as elaborated below.

Step 1: The LM-test (also referred to as the Fixed effect redundancy test) is applied to identify whether the pooled OLS or fixed effect model is better. If the $p$ value is less than the set $\alpha$ value, null hypothesis is rejected, and the decision is in favour of the Fixed Effect (FE) model.

Step 2: The Breusch-Pagan test is applied to compare pooled OLS with Random Effect (RE) model. If the $p$ value is less than the alpha value, null hypothesis is rejected, and the decision is in favour of the Random Effect (RE) model.

Step 3: In case Pooled OLS gets rejected in both the FE and RE models, the Hausman test is performed to make the final choice. If the null hypothesis is rejected, the decision is in favour of the FE model, else the RE model is used. 


\section{Estimating the Regression Models}

Step 1: Choosing between Pooled OLS model and Fixed Effect (FE) model

To make a choice between the Pooled OLS and FE models, first we perform the LM test. As per the result, the $F$ statistics for the Model 1 (dependent variable ROA) and Model 2 (dependent variable ROE) are 11.33 and 1.97, respectively. The $p$ values are 0.000 and 0.001 respectively which therefore rejects the null hypothesis at $1 \%$ level, favouring the FE model.

Step 2: Choosing between Pooled OLS model and Random Effect (RE) model

To choose between Pooled OLS and RE model, we perform the Breusch-Pagan test. The computed values of Wald $\chi^{2}$ for the two models are 11078.63 for Model 1 (dependent being ROA) and 89.31 for Model 2 (dependent variable ROE). Both these test statistics show a $p$ value of 0.000 which means that the null hypothesis is rejected at $1 \%$ level and RE model is found to be better than the Pooled OLS.

Step 3: Choosing between Fixed Effect model and Random Effect model

The researchers performed the Hausman test, which tests the null hypothesis that the random effect model is the consistent and efficient one. As per the results, the computed value of $\chi^{2}(4)$ is found to be significant at $1 \%$. Hence, the null hypothesis gets rejected and the decision goes in favour of the FE model.

\section{Estimating the Model with ROA as the Explained Variable}

Table 3 depicts some important findings obtained from the estimated fixed effect model (controlled for heteroscedasticity). RDI_LAG which is the one-year lag value of the intensity of R\&D expenditure has a negative coefficient of 0.792 which is significant at $1 \%$. In other words, the past R\&D expenditure fails to bring about a positive response on firm performance which contradicts the findings of $\mathrm{Xu}$ et al. (2016) who finds a positive relationship between lagged $R \& D$ and profitability measured by return on asset. However, the squared value of one-year lagged RDI has a positive coefficient of 0.002 which is also significant at the same level. This implies that there is a waiting time before the expenditure on $R \& D$ directly and positively impacts returns. This also shows that the relationship between ROA and the lagged RDI is not a linear one. Instead, it supports the quadratic nature of the relationship. After an initial fall in ROA with rise in the value of lagged RDI, the firm performance shows an upward movement. Thus, we observe a U-shaped nature of the curve.

The findings of this study are in line with that of Holzl (2009) who finds the occurrence of a positive effect of $R \& D$ investment only after a certain level of $R \& D$ 
intensity in the case of small and medium enterprises. On a similar note, Audretsch et al. (2004) mentions that investment in R\&D helps corporates to attain a minimum scale / size so as to generate benefits and ensure benefits. Nunes et al. (2012) also find a U-shaped curve between RDI and growth with the initial phase showing negative growth which, however, reverses beyond a certain point.

Table 3: Factors Affecting ROA

\begin{tabular}{|c|c|c|c|c|c|}
\hline \multirow[t]{2}{*}{ Variables } & \multicolumn{2}{|c|}{ FE model } & $\begin{array}{l}\text { FE model } \\
\text { (under } \\
\text { robust } \\
\text { condition) }\end{array}$ & \multicolumn{2}{|c|}{ RE model } \\
\hline & Coefficient & $\mid t$-stat $\mid$ & $\mid t$-stat $\mid$ & Coefficient & |Z-Stat $\mid$ \\
\hline Intercept & 37.336 & 9.98 & 8.78 & 39.846 & 12.02 \\
\hline RDI_LAG & -0.792 & $2.91 * * *$ & $2.31 * * *$ & -0.789 & $7.59 * * *$ \\
\hline RDI_LAGSQ & 0.002 & $3.52 * * *$ & $2.97 * * *$ & 0.002 & $5.30 * * *$ \\
\hline FIN_RISK & -1.035 & $134.67 * * *$ & $128.32 * * *$ & -1.018 & $98.11 * * *$ \\
\hline LIQUIDITY & 2.026 & $2.01 * *$ & $1.34 * *$ & 0.897 & 0.84 \\
\hline R-sq.: within & 0.9837 & - & 0.9837 & 0.9836 & - \\
\hline : between & 0.8793 & - & 0.8793 & 0.8824 & - \\
\hline : overall & 0.9674 & - & 0.9674 & 0.9675 & - \\
\hline$F$-test: $F(37,315)$ & 11.33 & - & - & - & - \\
\hline Wald $\chi^{2}$ & - & - & - & $11078.63^{* * *}$ & - \\
\hline
\end{tabular}

Notes: $1 . * * *$ and $* *$ denote significance levels $p<0.01$ and $p<0.05$, respectively.

2. Under the robust condition, though the coefficients remain unchanged, there is a change in the value of test statistic.

The finding, however, contradicts the observation in Fredriksson and Wikberg (2015) but duly recognises the importance of lagged expenditure. This is an important finding that has implications for R\&D decisions of an enterprise. Thus, the finding agrees with some of the previous studies that identify the important role of lag in the relationship. The nature of the relationship shows that the benefits of RDI arise after a certain time gap. The results show that the impact of lagged RDI on firm performance is initially negative. However, the positive impact is felt after a certain value of the variable as evident from the positive coefficient of quadratic term. Hence, the finding has implication for managers who should be aware of the fact that the quantum of investment on R\&D (on one-year lag basis) needed before the corporate begins to realise the benefits of such expenditure is quite high. Thus, the benefits can 
be realised to a larger extent by big-sized players in the sector. It, however, does not imply that they should stop incurring the expenditure because without $R \& D$, it is simply not possible to survive in the market. Instead of cutting down on the $R \& D$ budget, it is essential for managers to think about cost management in non-core areas together with market expansion and product expansion in order to have an overall positive effect on the ROA. Furthermore, the results point to the need for consolidation in the industry which is possible because it already shows high concentration ratio with a few players capturing majority of the market share. It is quite possible that due to this reason the industry has been witnessing a series of mergers. Some of the prominent cases include the acquisition of Ranbaxy by Sun Pharma, Piramal Health by Abbott and Gavin by Lupin. The acquisition of Taro by Sun Pharma was another significant case in point.

The necessity of huge spending need on this head arises because corporates work on the production of new products (or molecules in the case of pharmaceutical industry) and new processes and for this huge expenditure is met though the return is not guaranteed in many cases. The realisation of gains from the expenditure can be obtained but with a lag as obvious from the consideration of the lagged variable of the R\&D intensity. The research supports a U-shaped curve of the relationship between the dependent variable and value of the lagged RDI. If lagged RDI and firm performance are measured on horizontal and vertical axes, respectively, a parabola shaped curve can be obtained with the opening faced up. Thus, it can be said that the quadratic nature of the curve shows that until a certain point of lagged RDI is reached, the positive effect on performance cannot be seen. This conclusion, however, contradicts the inverse S-shaped curve as obtained in the study by Wang (2011). An interesting point is that there is a minimum/threshold level of expenditure below which benefits are not obtained which was also supported by Kotabe et al. (2002).

Both the control variables are found to have a significant effect. The implication of the result on financial leverage is not surprising. The negative sign of the financial risk variable shows that increase in the amount of debt fund in the capital structure leads to a deteriorating effect on the return which will be more when the financial obligations exceed the extra benefits generated from that capital. The corporate houses in this sector are found to be highly leveraged which is clear from the descriptive statistics as a result of which the interest load is a huge one. The findings though match with those of Le and Phan (2017), Khan (2012), Gill et al. (2009) and Yoon and Jang (2005) contradict those of Avci (2016) and Yazdanfar and Ohman (2015). 
The prescribed model establishes the effect of liquid capital on ROA to be a positive one which contradicts the traditional knowledge of an inverse relationship between the two. In other words, the industry structure supports the keeping of more amount of liquid assets as it helps in the efficient business operations. In fact, as we know from the basics of finance that the liquidity ratio varies from one industry to another. Here, a higher amount of liquid capital contributes positively to a higher ROA. There are a few studies that support this result (Pimentel et al., 2005; Hirigoyen, 1985) but it goes against the findings of Lamberg and Vålming (2009) and Padachi (2006) which find no significant relationship. The next sub-section shows the results in the case of ROE as the response variable.

\section{Estimating the Model with ROE as the Explained Variable}

With regard to the model in which ROE is considered as the dependent variable, it is observed from Table 4 that the one-year lagged RDI and its quadratic term show similar behaviour in respect of sign (being negative) and significance (at $1 \%$ level).

Table 4: Factors Affecting ROE

\begin{tabular}{|c|c|c|c|c|c|}
\hline \multirow[t]{2}{*}{ Variables } & \multicolumn{2}{|c|}{ FE model } & $\begin{array}{l}\text { FE model } \\
\text { (under } \\
\text { robust } \\
\text { condition) }\end{array}$ & \multicolumn{2}{|c|}{ RE model } \\
\hline & Coefficient & $\mid t$ - stat $\mid$ & $\mid t$-stat $\mid$ & Coefficient & $\mid Z$-Stat $\mid$ \\
\hline Intercept & 0.281 & $2.22 * *$ & $3.99 * * *$ & 0.169 & 3.76 \\
\hline RDI_LAG & -0.019 & $-4.26 * * *$ & $5.15 * * *$ & -0.009 & $6.64 * * *$ \\
\hline RDI_LAGSQ & 0.00004 & $4.33 * * *$ & $5.48 * * *$ & 0.00002 & $4.55 * * *$ \\
\hline FIN_RISK & 0.0006 & $4.75 * * *$ & $9.32 * * *$ & 0.00069 & $5.38 * * *$ \\
\hline LIQUIDITY & 0.027 & 1.58 & 1.30 & 0.0422 & $2.96 * * *$ \\
\hline R-sq.: within & 0.1468 & - & 0.1468 & 0.1348 & - \\
\hline : between & 0.4848 & - & 0.4848 & 0.5024 & - \\
\hline : overall & 0.2133 & - & 0.2133 & 0.2387 & - \\
\hline$F$-test: $F(37,315)$ & $1.97 * * *$ & - & - & - & - \\
\hline Wald $\chi^{2}$ & - & - & - & $89.31 * * *$ & - \\
\hline $\begin{array}{ll}\text { Notes: } & 1 . * * * \text { and } \\
& \text { 2. Under th } \\
& \text { the valu }\end{array}$ & hote signific & $\begin{array}{l}\text { e levels } p \\
\text { ough the } c\end{array}$ & $\begin{array}{l}0.01 \text { and } p<0 \\
\text { fficients rema }\end{array}$ & $\begin{array}{l}\text { respectively. } \\
\text { inchanged, the }\end{array}$ & change in \\
\hline
\end{tabular}

Thus, beyond a certain level, there is a positive impact on ROE. The study by Chiou and Lee (2011) emphasized the inflexion point. The explanation for this is the same as mentioned in the earlier case of ROA. The positive effect on ROE is a result 
of the low level of debt fund in the capital structure (Frydenberg, 2011). This low debt financing follows the pecking order hypothesis where managers support financing using internal accruals after which they go for debt financing. The result is in line with the findings in Weill (2004) and Brav (2009). The variable 'liquidity' has a positive but an insignificant impact on performance which is in line with the findings by Taani (2012). In the discussion of the results from Model 1, there is a mention about the previous studies with which the findings match and disagree with regard to the effect on financial performance.

\section{Conclusions and Implications for Practice}

On the basis of the gap existing in the previous studies, this empirical research aims to find out the nature of the relationship between investment on $R \& D$ and firm performance. Also, the study throws light on the idea that there is a positive impact on performance after a certain level of lagged RDI. In this respect, the research does a valuable contribution to the literature in this field. The present study looks into an issue that has been confusing researchers for a long time. The issue of connectedness between spending on R\&D and firm performance has already been delved upon by previous researchers but there is lack of agreement in terms of the effect and direction of the impact. Moreover, there are a few gaps that have been identified which mainly include the time lag of the impact of RDI on firm performance and identification of the correct form of the model. In fact, we found that only a few earlier studies have determined the optimal level of expenditure on R\&D. Thus, we explored into these areas that have either not been investigated before or have contradictory findings.

The researchers find interesting results on the issue. This empirical work recognises that the linear form which has been used in most of the previous studies did not suit well in the case of pharmaceutical companies in India. In fact, the quadratic form is a better fitting model which exhibits a U-shaped curve. Identification of this nature of a curve connecting the two issues is an exploration not looked at by Indian researchers. The U-shaped relationship comprehensively shows the non-linear aspect. It therefore removes an element of doubt on the issue of time gap between incurrence of the expenditure and effect on financial outcomes. The derived curve shows that initially due to the huge spending by the corporate under this head, there is an initial pressure on profitability measures like Return on Asset and Return on Equity in the first phase but in the second phase after a time lag, there is a positive impact on profitability. Thus, it is not just that the issue of time lag is vital, but it is also necessary to understand how the returns move with the values of lagged research and development. On the basis of this study, one can realise that 
managers of pharmaceutical industries should not expect $R \& D$ expenditures to work magic by instantly having an impact on performance. The corporate heads have to keep this in mind and decide appropriate policies regarding R\&D so that frustration does not creep in. This is a study that has implications for strategies at the functional level.

The research outcomes will definitely provide cue to $R \& D$ heads in corporate levels. However, there is scope for further improvement in similar studies. The first limitation is that the focus is only on a particular industry which poses constraints in making a generalised comment on the subject. For further research, investigators can consider several industries together so as to capture the effect of industries that can have a moderating effect on the relationship between Investment on R\&D and firm performance. The second limitation arises from the fact that in the case of the Indian pharmaceutical industry, there are several companies that invest minimal amounts on this head. Thus, the analysis can also be done group-wise to find whether these results are valid for all the groups or not. We encourage researchers to consider these issues while undertaking further studies in this aspect.

\section{Acknowledgements}

The researchers duly acknowledge the contribution of the reviewers by sharing their valuable comments and suggestions which helped to improve the quality of the submission.

\section{Declaration of Conflicting Interests}

The authors declared no potential conflicts of interest with respect to the research, authorship, and publication of this article.

\section{References}

Al-Horani, A., Pope, P. F., \& Stark, A. W. (2003). Research and development activity and expected return in the United Kingdom. Review of Finance, 7(1), 27-46. https://doi.org/10.1023/A:1022504029943

Audretsch, D. B., Klomp, L., Santarelli, E., \& Thurik, A. R. (2004). Gibrat's law: Are the services different? Review of Industrial Organization, 24, 301-324. https://doi.org/10.1023/B:REIO.0000038273.50622.ec

Ayaydin, H., \& Karaaslan, İ. (2014). The effect of research and development investment on firms' financial performance: Evidence from manufacturing 
firms in Turkey. Bilgi Ekonomisi ve Yönetimi Dergisi, 9(2). 43-59

https://dergipark.org.tr/en/pub/beyder/issue/3469/47188

Avci, E. (2016). Capital structure and firm performance: An application on manufacturing industry. Iktisadi ve Idari Bilimler Dergisi, 38(1), 15-30. https://doi.org/10.14780/iibd.81334

Bae, S. C., Park, B. J., \& Wang, X. (2008). Multinationality, R\&D intensity and firm performance: Evidence from U.S. manufacturing firms. Multinational Business Review, 16(1), 53-78. https://doi.org/10.1108/1525383X200800003

Baptista, R., \& Karaoz, M. (2009). Turbulence in growing and declining industries. Small Business Economics, 36(3), 249-270. https://doi.org/10.1007/s11187-009-9226-2

Beise-Zee, R., \& Rammer, C. (2006). Local user-producer interaction in innovation and export performance of firms. Small Business Economics, 27, 207-222. https://doi.org/10.1007/s11187-006-0013-z

Beld, B. (2014). The effect of $R \& D$ investment on firm performance. [Bachelors dissertation, University of Twente]. University of Twente student theses. http://purl.utwente.nl/essays/66303

Brav, O. (2009). Access to capital, capital structure, and the funding of the firm. The Journal of Finance. 64(1), 263-308. https://doi.org/10.1111/j.15406261.2008.01434.x

Brenner, M.S., \& Rushton, B.M. (1989). Sales growth and R\&D in the chemical industry. Research-Technology Management, 32(2), 8-15. https://doi.org/10.1080/08956308.1989.11670580

Chai, X. K. (2012). Research on the influence of R\&D investment on enterprise performance-Evidence from the pharmaceutical and biological products listed companies. Journal of the Postgraduate of Zhongnan University of Economics and Law, 28(1), 63-73.

Chaklader, B., \& Chawla, D. (2016). A study of determinants of capital structure through panel data analysis of firms listed in NSE CNX 500. Vision: The Journal of Business Perspective, 20(4), 267-277. https://doi.org/10.1177/0972262916668700

Chen, T.-C., Guo, D.-Q., Chen, H.-M., \& Wei, T.-T. (2019). Effects of R\&D intensity on firm performance in Taiwan's semiconductor industry. Economic Research-Ekonomska Istrazivanja, 32(1), 2377-2392. https://doi.org/10.1080/1331677X.2019.1642776

Chiou, J.-S., \& Lee, Y.-C. (2011). Efficiency and profitability on biotech-industry in small economy. International Journal of Business and Commerce, 1(2), 124. https://www.ijbcnet.com/1-2/IJBC-11-1201.pdf 
Dai, M., \& Yu, M. (2013). Firm R\&D, absorptive capacity and learning by exporting: Firm-level evidence from China. The World Economy, 36 (9), 11311145. https://doi.org/10.1111/twec.12014

Deloof, M. (2003). Does working capital management affect profitability of Belgian firms? Journal of Business and Finance Accounting. 30, 573-588. https://doi.org/10.1111/1468-5957.00008

Dharni, K. (2017). Linking R\&D activities and firm performance a study of Indian manufacturing sector. National Science \& Technology Management Information System Division, Department of Science \& Technology, India. http://digitalrepository-nstmis-dst.org/pcr/es/231/231/Full-Text-Report.pdf

Falk, M. (2012) Quantile estimates of the impact of R\&D intensity on firm performance. Small Business Economics, 39(1), 19-37. https://doi.org/10.1007/s11187-010-9290-7

Fredriksson, N., \& Wikberg, J. (2015). The relationship between $R \& D$ spending and firm economic performance: A regression study of firms in the industrial equipment manufacturing industry (Report No. E 2015:023) [Master's dissertation, Chalmers University of Technology]. Chalmers Open Digital Repository. https://odr.chalmers.se/bitstream/20.500.12380/218108/1/218108.pdf

Freihat, A. R. F., \& Kanakriyah, R. (2017). Impact of R\&D expenditure on financial performance: Jordanian evidence. European Journal of Business and Management, 9(32), 73-83.

https://www.iiste.org/Journals/index.php/EJBM/article/view/39612

Fryxel, G. E. (1990) Multiple outcomes from product R\&D: Profitability under different strategic orientations. Journal of Management, 16(3), 633-646. https://doi.org/10.1177/014920639001600308

Friedman, M. (1970, September 13). A Friedman doctrine: The social responsibility of business is to increase its profits. The New York Times.

https://www.nytimes.com/1970/09/13/archives/a-friedman-doctrine-the-socialresponsibility-of-business-is-to.html

Frydenberg, S. (2011). Capital structure theories and empirical tests: An overview.

In H. K. Baker \& G. S. Martin (Eds.), Capital structure and corporate financing decisions (pp. 127-149). John Wiley \& Sons. https://doi.org/10.1002/9781118266250.ch8

Garcia Osma, B., \& Young, S. (2009). R\&D expenditure and earnings targets. European Accounting Review, 18(1), 7-32. https://doi.org/10.1080/09638180802016718

Ghaffar, A., \& Khan, W.A. (2014). Impact of research and development on firm performance. International Journal of Accounting and Financial Reporting, 4(1), 357-367. https://doi.org/10.5296/ijafr.v4i1.6087 
Gill, A., Biger, N., Pai, C., \& Bhutani, S. (2009). The determinants of capital structure in the service industry: Evidence from United States. The Open Business Journal, 2, 48-53. https://benthamopen.com/ABSTRACT/TOBJ-2-48

Griffith, R., Huergo, E., Mairesse, J., \& Peters, B. (2006). Innovation and productivity across four European countries. Oxford Review of Economic Policy, 22(4), 483-498, https://doi.org/10.1093/oxrep/grj028

$\mathrm{Gu}, \mathrm{L}$. (2016). Product market competition, R\&D investment, and stock returns. Journal of Financial Economics, 119(2), 441-455. https://doi.org/10.1016/j.jfineco.2015.09.008

Guo, D., Guo, Y., \& Jiang, K. (2016). Government-subsidized R\&D and firm innovation: Evidence from China. Research Policy, 45(6), 1129-1144. https://doi.org/10.1016/j.respol.2016.03.002

Hall, B. H., Mairesse, J., \& Mohnen, P. (2009). Measuring the returns to $R \& D$ (NBER Working Paper 15622). National Bureau of Economic Research, USA. https://www.nber.org/papers/w15622

Harrison, J.S. (2003). Strategic Management of Resources and Relationships. Wiley.

Hirigoyen, G. (1985). Rentabilité et solvabilite [Profitability and solvency]. Direction et Gestion, 3, 13-26.

Ho, Y. K., Keh, H. T., \& Ong, J. M. (2005). The effects of R\&D and advertising on firm value: an examination of manufacturing and non-manufacturing firms. IEEE Transactions of Engineering Management, 52 (1), 3-14. https://doi.org/10.1109/tem.2004.839943

Holzl, W. (2009). Is the R\&D behaviour of fast-growing SMEs different? Evidence from CIS III data for 16 countries. Small Business Economics, 33, 59-75. https://doi.org/10.1007/s11187-009-9182-x

Hsu, F.-J., Chen, M.-Y., Chen, Y.-C., \& Wang, W. (2013). An empirical study on the relationship between R\&D and financial performance. Journal of Applied Finance \& Banking, 3(5), 107-119.

https://www.scienpress.com/journal_focus.asp?main_id=56\&Sub_id=IV\&Issue $=835$

Ibrahim, S. S. (2017). The impact of liquidity on profitability in banking sector of Iraq: A case of Iraqi commercial banks. International Journal of Finance and Banking Studies, 6(1), 113-121. https://doi.org/10.20525/ijfbs.v6i1.650

Jaisinghani, D. (2016). Impact of R\&D on profitability in the pharma sector: An empirical study from India. Journal of Asia Business Studies, 10(2), 194-210. https://doi.org/10.1108/JABS-03-2015-0031

Jirasek, M. (2017). The relationship between R\&D spending instability and a firm's performance. In T. Mokoaleli-Mokoteli \& Z. Ndaba (Eds), Proceedings of the 5th international conference on management, leadership and governance (pp. 
495-502). Academic Conferences and Publishing International. http://toc.proceedings.com/34017webtoc.pdf

Joseph, R. K. (2011). The R\&D scenario in Indian pharmaceutical industry (RIS Discussion Paper, No. 176). Research and Information System for Developing Countries. https://www.ris.org.in/rd-scenario-indian-pharmaceutical-industry

Kathuria, V. (2008). The impact of FDI inflows on R\&D investment by mediumand high-tech firms in India in the post-reform period. Transnational Corporations, 17(2), 45-66. https://digitallibrary.un.org/record/643909? ln=en

Khajavi, S., \& Sadeghnia, M. (2016). Investigating the impact of research and development costs on performance of loss firms: Evidence from Tehran Stock Exchange. International Journal of Humanities and Cultural Studies, Special issue (May), 765-775. https://www.ijhcs.com/index.php/ijhcs/article/view/804/706

Khan, A. G. (2012). The relationship of capital structure decisions with firm performance: A study of the engineering sector of Pakistan. International Journal of Accounting \& Financial Reporting, 2(1), 245-262. https://doi.org/10.5296/ijafr.v2i1.1825

Kotabe, M., Srinivasan, S. S., \& Aulakh, P. S. (2002) Multinationality and firm performance: The moderating role of R\&D and marketing capabilities. Journal of International Business Studies, 33(1), 79-97. https://doi.org/10.1057/palgrave.jibs.8491006

Kumar, N., \& Saqib, M. (1996) Firm size, opportunities for adaptation and in-house R\&D activity in developing countries: The case of Indian manufacturing. Resource Policy, 25(5), 713-722. https://doi.org/10.1016/0048-7333(95)008543

Lamberg, S., \& Vålming, S. (2009). Impact of liquidity management on profitability: A study of the adaption of liquidity strategies in a financial crisis. [Masters dissertation, Umeå School of Business]. DiVA. https://www.divaportal.org/smash/get/diva2:282882/FULLTEXT01.pdfImpact

Le, T. P. V., \& Phan, T. B. N. (2017). Capital structure and firm performance: Empirical evidence from a small transition country. Research in International Business and Finance, 42, December, 710-726. https://doi.org/10.1016/j.ribaf.2017.07.012

Lee, M., \& Choi, M. (2015). Analysis on time-lag effect of research and development investment in the pharmaceutical industry in Korea. Osong Public Health Research Perspective, 6(4), 241-248. https://doi.org/10.1016/j.ribaf.2017.07.012

Liao, Z. J. (2013). Empirical research on the correlations between R\&D investment, technological innovation and firm performance. Technology Economics, 32(1), 19-23. 
Lu, Y. M., \& Wang, C. M. (2011). Effect of R\&D investment on performance of Chinese listed companies-take manufacturing and IT industry as an example. Science and Technology Management Research, 5(5), 122-127.

Mahajan, M. M. (2011). The emergence of new R\&D paradigms in the Indian pharmaceutical industry: Post TRIPS Period. Journal of Intellectual Property Rights, 16(4), 321-329.

Makris, I. A. (2016). The effect of innovative activity in firm performance and development: Analysing data from Eurozone. International Journal of Business and Economic Sciences Applied Research, 9(2), 87-92.

Mishra, P., \& Chandra, T. (2010). Mergers, acquisitions and firms' performance: Experience of Indian pharmaceutical industry. Eurasian Journal of Business and Economics, 3 (5), 111-126.

McDaniel, B. A. (2002). Entrepreneurship and innovation: An economic approach. ME Sharpe.

Mulero Mendigorri, E., Garcia Vallderama, T., \& Rodríguez Cornejo, V. (2016). Measuring the effectiveness of $R$ \& D activities: Empirical validation of a scale in the Spanish pharmaceutical sector. Management Decision, 54(2), 321362. https://doi.org/10.1108/MD-06-2014-0378

Mishra, P. (2011). R\&D efforts by Indian pharmaceutical firms in the new patent regime. South East European Journal of Economics \& Business, 5(2), 83-94. https://doi.org/10.2478/v10033-010-0018-z

Naik, P. K., Krishnan, N., \& Padhi, P. (2012). R\&D intensity and market valuation of firm: A study of $R \& D$ incurring manufacturing firm in India (MPRA Paper No. 37299). MPRA. https://mpra.ub.uni-muenchen.de/37299/

Nunes, P. M., Sarrasqueiro, Z., \& Leitao, J. (2012). Is there a linear relationship between R\&D intensity and growth? Empirical evidence of non-high-tech vs. high-tech SMEs. Research Policy, 41(1), 36-53.

https://doi.org/10.1016/j.respol.2011.08.011

Padachi, K. (2006). Trends in working capital management and its impact on firms' performance: An analysis of Mauritian small manufacturing firms. International Review of Business Research Papers, 2(2), 45-58.

Pantagakis, E., Terzakis, D., \& Arvanitis, S. (2012). $R \& D$ investments and firm performance: An empirical investigation of the high technology sector (software and hardware) in the E.U. SSRN. http://dx.doi.org/10.2139/ssrn.2178919

Parameswaran, M. (2010). International trade and R\&D investment: Evidence from manufacturing firms in India. International Journal of Technology and Globalisation, 5(1-2), 43-60. http://www.inderscience.com/offer.php?id=33665

Parcharidis, E., \& Varsakelis, N. C. (2007). Investments in $R \& D$ and business performance: Evidence from the Greek market [Working Paper]. Department of Economics, Aristotle University of Thessaloniki. 
Peters, B., Roberts, M.J., Vuong, V.A., \& Fryges, H. (2013). Estimating dynamic $R \& D$ demand: An analysis of costs and long-run benefits (NBER Working Paper 19374). National Bureau of Economic Research, USA. https://www.nber.org/papers/w19374

Pimentel, R. C., Braga, R., \& Casanova, S. P. C. (2005). Interaction between profitability and liquidity: an exploratory study. Accounting Journal of the Master of Science in Accounting, UERJ, Rio de Janeiro, 10(2), 83-98.

Pradeep, V., Bhattacharya, M., \& Chen, J.-R. (2017). Spillover effects of research and development, exports and foreign investment on productivity: Empirical evidence from Indian manufacturing. Journal of South Asian Development, 12(1), 18-41. https://doi.org/10.1177/0973174117700467

Pradhan, J. P. (2011). R\&D strategy of small and medium enterprises in India. Science, Technology and Society. 16(3), 373-395. https://doi.org/10.1177/097172181101600307

Pradhan, R. S., \& Shrestha, D. (2017). Impact of liquidity on bank profitability in Nepalese commercial banks. SSRN. http://dx.doi.org/10.2139/ssrn.3044041

Purkayastha, S., Manolova, T. S., \& Edelman, L. F. (2018). Business group effects on the R\&D intensity-internationalization relationship: Empirical evidence from India. Journal of World Business, 53(2), 104-117. https://doi.org/10.1016/j.jwb.2016.11.004

Rao, J., Yu, Y., \& Cao, Y. (2013). The effect that R\&D has on company performance: Comparative analysis based on listed companies of technique intensive industry in China and Japan. International Journal of Education and Research, 1(4), 1-8.

Ravenscraft, D., \& Scherer, F.M. (1982). The lag structure of returns to research and development. Applied Economics, 14(6), 603-620. https://doi.org/10.1080/00036848200000036

Raykov, E. (2017). The liquidity-profitability trade-off in Bulgaria in terms of the changed financial management functions during crisis. Management, 22(1), 135-156. https://doi.org/10.30924/mjcmi/2017.22.1.135

Rehman, N. U. (2016). Does internal and external research and development affect innovation of small and medium-sized enterprises? Evidence from India and Pakistan (ADBI Working paper 577). Asian Development Bank Institute. https://doi.org/10.2139/ssrn.2800101

Ren, L., \& Wang, Z. (2013). Research of R\&D marginal productivity driving economic convergence. In P. Li (Ed.), Proceedings of the 2013 conference on education technology and management science (ICETMS 2013) (pp. 949-952). Atlantis Press. https://doi.org/10.2991/icetms.2013.258

Sasidharan, S., Lukose, P. J. J., \& Komera, S. (2015). Financing constraints and investments in R\&D: Evidence from Indian manufacturing firms. Quarterly 
Review of Economic and Finance, 55, 28-39.

https://doi.org/10.1016/j.qref.2014.07.002

Sharma, C. (2011). RD and productivity in the Indian pharmaceutical firms (MPRA Paper No. 31681). MPRA. https://mpra.ub.uni-muenchen.de/31681/

Sheikh, N.A., Wang, Z., \& Khan, S. (2013). The impact of internal attributes of corporate governance on firm performance. International Journal of Commerce and Management, 23(1), 38-55. https://doi.org/10.1108/10569211311301420

Shelton, R. \& Percival, D. (2013). Breakthrough innovation and growth: Top innovators expect US\$250 billion five-year revenue boost. pwc. https://www.pwc.co.uk/assets/pdf/achieving-business-growth.pdf.

Shi, C. (2003). On the trade-off between the future benefits and riskiness of R\&D: A bondholders' perspective. Journal of Accounting and Economics, 35(2), 227 254. https://doi.org/10.1016/S0165-4101(03)00020-X

Simerly, R.L. \& Li, M. (2000). Environmental dynamism, capital structure and performance: A theoretical integration and an empirical test. Strategic Management Journal, 21(1), 31-49. https://doi.org/10.1002/(sici)10970266(200001)21:1\%3C31::aid-smj76\%3E3.0.co;2-t

Singh, A. P. (2016). R\&D spill overs \& productivity growth: Evidence from Indian manufacturing. The Indian Journal of Industrial Relations, 51(4), 563-578.

Sougiannis, T. (1994). The accounting based valuation of corporate R\&D. Accounting Review, 69(1), 44-68.

Taani, K. (2012). Impact of working capital management policy and financial leverage on financial performance: empirical evidence from Amman stock exchange listed companies. International Journal of Management Sciences and Business Research, 1(8), 10-17.

Thomas, R., \& Narayanan, K. (2017). Determinants of outward foreign direct investment: A study of Indian manufacturing firms. Transnational Corporations, 24(1), 9-26. https://doi.org/10.18356/43478432-en

Tubbs, M. (2007). The relationship between R\&D and company performance. Research Technology Management, 50(6), 23-30. https://doi.org/10.1080/08956308.2007.11657470

Tyagi, S., \& Nauriyal, D. K. (2016). Profitability determinants in Indian drugs and pharmaceutical industry: An analysis of pre and post TRIPS period. Eurasian Journal of Business and Economics, 9(17), 1-21. https://doi.org/10.17015/ejbe.2016.017.01

Vithessonthi, C., \& Racela, O. C. (2016). Short-and long-run effects of internationalization and R\&D intensity on firm performance. Journal of Multinational Financial Management, 34, 28-45. https://doi.org/10.1016/j.mulfin.2015.12.001 
Wang, C.-H. (2011). Clarifying the effects of R\&D on performance: Evidence from the high technology industries. Asia Pacific Management Review, 16(1), 51-64.

Wang, H.-W., \& Wu, M.-C. (2012). Business type, industry value chain, and R\&D performance: Evidence from high-tech firms in an emerging market.

Technological Forecasting and Social Change, 79(2), 326-340. https://doi.org/10.1016/j.techfore.2011.05.008

Weill, L. (2004). What determines leverage in transition countries? Czech Journal of Economics and Finance, 54(5-6), 234-242. http://journal.fsv.cuni.cz/storage/973_s_234_242.pdf

World Bank Group. (2020). Research and development expenditure (\% of GDP). https://data.worldbank.org/indicator/GB.XPD.RSDV.GD.ZS

Xu, J., Sim, J.-W., \& Jin, Z. (2016). Research on the impact of R\&D investment on firm performance and enterprise value based on multiple linear regression model and data mining. International Journal of Database Theory and Application, 9(11), 305-316. http://article.nadiapub.com/IJDTA/vol9_no11/27.pdf

Xu, J., \& Jin, Z. (2016). Research on the impact of R\&D investment on firm performance in China's internet of things industry. Journal of Advanced Management Science, 4(2), 112-116.

http://www.joams.com/index.php?m=content\&c=index \&a=show\&catid=47\&id $=249$

Yazdanfar, D., \& Ohman, P. (2015). Debt financing and firm performance: An empirical study based on Swedish data. The Journal of Risk Finance, 16(1), 102-118. https://doi.org/10.1108/JRF-06-2014-0085

Yoon, E., \& Jang, S.-C. (2005). The effect of financial leverage on profitability and risk of restaurant firms. Journal of Hospitality Financial Management. 13(1), 35-47. https://doi.org/10.1080/10913211.2005.10653798

Zhao, X.C., \& Wu, J.X. (2013). Comparative research on R\&D investment and performance of listed companies on SMEs board. Science and Technology Management Research, 12(12), 104-108. http://en.cnki.com.cn/Article_en/CJFDTOTAL-KJGL201312022.htm

Zhao,Y. H. \& Xu, M. (2013). Research of the influence of R\&D input on enterprises' performance: Based on the panel data of the Yangtze Delta from 2006 to 2010. Science and Technology Management Research, 32(12), 95-98. https://caod.oriprobe.com/articles/38932435/Research_of_the_Influence_of_R_ D_Input_on_Enterpri.htm

Zhu, Z., \& Huang, F. (2012). The effect of R\&D investment on firms' financial performance: Evidence from the Chinese listed IT firms. Modern Economy, 3(8), 915-919. 